\title{
MYKOLO ROMERIO UNIVERSITETO STUDENTŲ PATIRIAMO STRESO IVEIKOS STRATEGIJOS
}

\author{
Jolita Dudaitè \\ Mykolo Romerio universiteto \\ Socialinių technologijų fakulteto \\ Edukologijos ir socialinio darbo institutas \\ Ateities g. 20, LT-08303 Vilnius, Lietuva \\ Tel.: (+ 370 5) 2714710 \\ El.paštas: jolitad@mruni.eu \\ Stasè Ustilaitė \\ Lietuvos edukologijos universiteto \\ Sporto ir sveikatos fakulteto \\ Sveikatos ir fizinio ugdymo katedra \\ Studentų g. 39, LT-08106 Vilnius, Lietuva \\ Tel.: (+ 370 5) 2790542 \\ El. paštas: stase.ustilaite@leu.lt
}

Pateikta 2014 m. sausio 3 d., parengta spausdinti 2014 m. gruodžio 10 d.

doi:10.13165/SMS-14-6-3-11

\section{Anotacija.}

Tyrimo tikslas - nustatyti, kokias streso įveikos strategijas taiko Mykolo Romerio (MRU) universiteto studentai. Tyrimo imtis: atsitiktiniu büdu atrinkti MRU visu kursų studentai. Imties dydis - 450 respondentų. Rezultatai ir išvados. Tyrimo duomenys rodo, kad 90 proc. respondentu patiria stresą. Moterys linkusios stresa jausti dažniau nei vyrai. Daugiau nei pusé respondenčiu (51,8 proc.) nurodè, kad stresa jaučia dažnai arba labai dažnai, tuo tarpu taip atsaké mažiau nei ketvirtadalis vyru (23,6 proc.). Stresą lemiančiu veiksniu faktoriné analizé atskleidè, kad studentams dažniausiai stresa 
sukeliančius veiksnius galima sugrupuoti į tris faktorius: socialiniai santykiai; kasdiene įtampa; studijos. Nustatyta, kad MRU studentams büdinga triju faktoriu streso įveikos strategiju struktūra: pozityvi savipagalba; ieškojimas kitu pagalbos - žmonių, Dievo, medicinos; negatyvi savipagalba.

Reikšminiai žodžiai: studentu stresas, streso ịveikimo strategijos.

\section{Ivadas}

Viena aktualiausių šiuolaikinio gyvenimo problemų yra stresas. Stresas - tai ypatingas asmens ir aplinkos santykis, kuris asmens yra ịvertintas kaip apsunkinantis arba viršijantis jo turimus išteklius ir keliantis grèsmę gerovei ${ }^{1}$. Stresas tiesiogiai ar netiesiogiai skatina susirgimą įvairiomis rimtomis ligomis: koronarine širdies liga, vežiu, hipertenzija, didina nelaimingų atsitikimų, traumų ir savižudybių skaičių. Jis turi įtakos tokiems gyvenimo būdo pasikeitimams, kaip padidèjęs alkoholio, tabako, narkotikų vartojimas, sutrikęs miegas, sumažejęs fizinis aktyvumas, o tai turi ịtakos psichinei ir fizinei žmonių sveikatai².

Stresas veikia tiek fizinę, tiek psichikos sveikatą. Žmonės, patiriantys stiprų ilgalaikị stresą, gali prarasti socialinị ir emocinị stabilumą. Jie gali jausti nerimą, depresiją, sunkiai randa išeitị iš padèties. Su stresu yra susiję imuniniai pokyčiai, jis provokuoja alerginių ligų atsiradimąa ${ }^{3}$. Stresas yra svarbus psichikos ligų veiksnys, pabloginantis ligos požymius ir sukeliantis ligos paūmèjimus ${ }^{4}$. Lètinis stresas gali nulemti imuninès sistemos susilpnejiimą ir padidejjusị jautrumą ịvairioms infekcinèms ligoms ${ }^{5}$. Tipiškos streso sukeltos ligos gali būti skrandžio ir dvylikapirštės žarnos opaligè, migrena, hipertoninè liga, miokardo infarktas, kai kurios imuninès, alerginès ligos, psichikos sutrikimai. Žmonių, kuriuos ilgą laiką veikia intensyvus stresas, sergamumo ir mirtingumo rodikliai yra 1,8-2,2 karto aukštesni .

Studijos aukštojoje mokykloje yra reikšmingas gyvenimo ịvykis studentams. Nors tai vieta, teikianti galimybę augti ir tobulèti, tačiau akademiniai reikalavimai, finansiniai sunkumai ir socialiniai reikalavimai studentams gali sukelti stresą ${ }^{7}$. Jis būna

1 Bulotaitè, L., et al. Universitetų dėstytojų darbo ir streso ypatumai. Acta paedagogica Vilnensia. 2008, 21: 208-219.

2 Karkockienè, D. Medicinos ir sveikatos mokslų studentų patiriamo streso ypatumai ir jo ịtaka miego kokybei. Visuomenès sveikata. 2011, 2(53): 83-92.

3 De Kloet, E. R.; Joëls, M.; Holsboer, F. Stress and the brain: from adaptation to disease. Nature reviews: Neuroscience. 2005, 6(6): 463-475.

4 Mostafaei, A. The relationship between stress and mental health in university students. Scholars Research Library. Annals of Biological Research. 2012, 3(7): 3468-3473.

5 Zaborskis, A.; Vareikienè, I. Patyčios mokykloje ir jų sąsajos su moksleivių sveikata bei gyvensena. Medicina. 2008,44(3): 232-239.

6 Karkockienè, D., supra note 2, p. 83-92.

7 Sapranavičiūtè, L.; Perminas, A.; Kavaliauskaitè, E. Universiteto studentų stresogeninių situacijų ịveikos strategijų struktūra. Tarptautinis psichologijos žurnalas: biopsichosocialinis požiūris. 2011, 8: 9-28. 
susijęs su naujais iššūkiais ir sunkumais adaptuojantis prie akademinių krūvių, naujos socialinès ir fizinès aplinkos ${ }^{8}$. Studentai yra specifinè socialinè grupé, kuri daugiausia dèmesio skiria mokymuisi, taip pat nemaža jų dalis derina mokslą su darbu. Jie patiria stresą daugelyje akademinio ir asmeninio gyvenimo sričių ${ }^{9}$ Streso poveikis organizmui nemaža dalimi priklauso nuo galimybių ji îveikti. Nustatyta, kad depresija, elgesio sutrikimai, rūkymas, mažesnis fizinis aktyvumas, svaigalų vartojimas, blogesnè psichologinè savijauta bei prasta mityba yra susiję su netinkamai pasirenkama streso įveika ${ }^{10}$. Dèl asmens nesèkmingų pastangų susidoroti su stresu situacija perauga ị chroniško streso būseną ir tuomet pagausejja nusiskundimų sveikata ${ }^{11}$.

Sèkminga patiriamo streso įveika yra labai svarbi siekiant pagerinti studentų gyvenimo kokybę ir išvengti sunkių sveikatos sutrikimų ${ }^{12}$. Taikant sėkmingas streso ivveikos strategijas, gerejja pasitenkinimas gyvenimu ir subjektyvi gerové $\dot{e}^{13}$. P. D. Welle ir H. M. Graf ${ }^{14}$ nurodo, kad streso lygis ir įveikos būdai nèra visiems vienodi: yra daug skirtumų, susijusių su lytimi, amžiumi, rase ir kt. Sportuojančių studentų (vyrų ir moterų) streso įveikos būdus nagrinèję V. Ivaškien $\dot{e}^{15}$ su bendraautoriais konstatuoja, kad vaikinai stresui ịveikti dažniausiai pasitelkia juoką, bendravimą su šeimos nariais ir pasivaikščiojimą gamtoje, o merginos - šokius, jogą ir savimasažą. A. Perminas, A. Galvydienè ${ }^{16}$, gilinęsi ị studentų sveikos mitybos bei streso ịveikos strategijų sąsajas nurodo, kad tiek vaikinų, tiek merginų prastesnè mityba susijusi su mažiau adaptyviu streso ịveikimu. R. Kausaro ${ }^{17}$ nuomone, jeigu studentai pasirenka aktyvią streso ịveikos strategiją, tai mokymosi krūvis jiems būna lengviau ịveikiamas. Aukštesnis emocinis intelektas ir didesnè jausmų kontrolè, kaip teigia J. Poro ir kt. ${ }^{18}$, gali padèti

8 Kausar, R. Perceived stress, academic workloads and use of coping strategies by university students. Journal of Behavioural Sciences. 2010, 20: 31-46; Norkus, A.; Alūzas, R. Studentu sveikatos ugdymas aukštosiose mokyklose: galimybès ir problemos. Studijos šiuolaikinèje visuomenèje. 2012, 3(1): 185-193.

9 Riddock, C. C. What to Do About Being Overwhelmed: Graduate Students, Stress and University Services. College Student Affairs Journal. 2007, 279(1): 24-44.

10 Perminas, A.; Galvydienè, A. Studentų sveikos mitybos bei streso ịveikimo strategijų sąsajos. Tarptautinis psichologinis žurnalas: biopsichosocialinis požiūris. 2008, 1: 71-85.

11 Sapranavičiūtè, L.; Permina, A. Universiteto studentų naudojamų streso įveikimo strategijų ir nusiskundimų sveikata sąsajos. Visuomenés sveikata. 2011, 1(52): 98- 107.

12 Karkockienè, D., supra note 2, p. 83-92.

13 Odaci, H.; Çıkrıkçı, Ö. University students' ways of coping with stress, life satisfaction and subjective well-being. Online journal of Counseling and education. 2012, 1(3): 117-130.

14 Welle, P. D.; Graf, H. M. Effective lifestyle habits and coping strategies for stress tolerance among college students. American Journal of Health Education. 2011, 42(2): 96-105.

15 Ivaškienè, V.; Kšanauskienè, L.; Čepelionienè, J.; Bogužienė, J.; Daukšas, D. Sportuojančių studentų (vyrų ir moterų) taikomi streso ịveikimo būdai. Socialiniai mokslai. 2009, 3(74): 28-33.

16 Perminas, A.; Galvydienè, A., supra note 10, p. 71-85.

17 Kausar, R., supra note 8, 31-46.

18 Por, J.; Barriball, L.; Fitzpatric, L.; Roberts, J. Emotional intelligence: Its relationship to stress, coping, well-being and professional performance in nursing students. Nurse Education Today. 2011, 31: 855-860. 
studentams taikyti aktyvias ir veiksmingas streso ịveikimo strategijas. Savikontrolè, emocijų valdymas - tai mechanizmai, kuriais individas gali efektyviai įveikti stresąa ${ }^{19}$.

Literatūroje yra nuorodų, kad nemažai studentų stresui ịveikti taiko daug neefektyvių streso ịveikos būdų ${ }^{20}$. Todèl, norint padèti studentams sèkmingai ịveikti stresą, reikia išsiaiškinti jų taikomus streso ịveikos būdus ir mokyti taikyti efektyviausius.

Tyrimo objektas: studentų stresas ir jo įveikos strategijos.

Tyrimo tikslas: nustatyti, kokias streso įveikos strategijas taiko Mykolo Romerio universiteto studentai.

\section{Tyrimo imtis ir metodai}

Tyrimas buvo atliekamas 2012 metų rugsëjo-gruodžio mènesiais Mykolo Romerio universitete. Tyrimui atlikti taikytas apklausos metodas, duomenų rinkimo instrumentas - klausimynas raštu. Naudojant anoniminị klausimyną aiškintasi, kaip dažnai ir kada studentai patiria stresą, kaip ji suvokia, kokie yra stresą sukeliantys veiksniai ir studentų pasirenkami streso įveikos būdai. Tyrimo imtị sudarè atsitiktiniu būdu atrinkti Mykolo Romerio universiteto studentai. Šio universiteto studentų populiacija yra 22000 . Taikant 5 proc. paklaidą apskaičiuota, kad siekiant gauti statistiškai reikšmingus rezultatus reikia apklausti 393 studentus. Iš anksto nežinant klausimyno grįžtamumo rodiklių, klausimynų išdalinta daugiau - 519. Klausimynai dalinti studentams atsitiktiniu būdu (imties tipas - paprasta atsitiktinè). 10 klausimynų buvo sugadinti arba negrąžinti. Iš viso užpildyta 509 klausimynų - daugiau nei reikalinga minimaliai apklausti. Apklausti visų kursų studentai - tiek bakalaurai, tiek magistrantai, studijuojantys tiek nuolatiniu, tiek ištęstiniu būdu. Apklaustųjų amžius - nuo 19 iki 42 metų. Akivaizdu, kad 19 ir 42 metų amžiaus asmenų gyvenimo sąlygos ir patiriamas stresas labai skiriasi. Toks didelis amžiaus intervalas galètų iškreipti tyrimo rezultatus ir todèl analizei nèra tinkamas. Todèl apsispręsta analizuoti tik 19-25 metų amžiaus studentų rezultatus - tokio amžiaus intervalo studentų universitete yra daugiausiai - ir atmesti 59 respondentų atsakymai. Galutinis imties dydis - 450. Tyrime dalyvavo 335 (74,4 proc.) moterys ir 115 (25,6 proc.) vyrų.

Rezultatų apdorojimui buvo naudojamas programinis statistinių duomenų paketas SPSS 17.0. Klausimyno klausimų vidinis suderinamumas skaičiuotas pagal Kronbacho alfa rodiklį. Skirstiniams palyginti taikytas Pearsono $\chi 2$ kriterijus. Ryšiui tarp kintamujų įvertinti taikyta Spearmano koreliacija. Kintamiesiems grupuoti naudota faktorinè analizè su Varimax sukiniu.

19 Houghton, J. D.; Wu, J.; Godwin, J. L.; Neck, C. P.; Manz, C. C. Effective stress management: a model of emotional intelligence, self-leadership, and student stress coping. Journal of Management Education. 2012, 36(2): 220-238.

20 Chylova, H.; Natovova, L. H. Stress coping strategies at university students - part I: gender differences. Journal on Efficiency and Responsibility in Education and Science. 2012, 5(3): 135147; Kausar, R., supra note 8, 31-46. 


\section{Rezultatai}

Studentų buvo paklausta, ar jie gyvenime jaučia stresą, ir jei jaučia, tai kaip dažnai. Dešimtadalis respondentų atsakè, kad niekada gyvenime nejaučia streso. Likusieji 90 proc. respondentų stresą jaučia, maždaug pusẻ iš jų nurodè, kad stresą jaučia dažnai, ir pusė - stresą jaučia kartais. Taigi matyti, kad stresas yra dažna studentų problema.

Pastebėta, kad vyrų ir moterų streso jautimo dažnis statistiškai reikšmingai skiriasi $\left(\chi^{2}=58,6,11=4, p<0,01\right)$. Moterys linkusios stresą jausti dažniau nei vyrai. Daugiau nei pusė respondenčių (51,8 proc.) nurodè, kad stresą jaučia dažnai arba labai dažnai, tuo tarpu taip atsakè mažiau nei ketvirtadalis vyrų (23,6 proc.). Labai dažnai stresą jaučia 17,1 proc. moterų ir 5,7 proc. vyrų. Niekada nejaučia streso tik 4,9 proc. moterų ir beveik ketvirtadalis (24,3 proc.) vyrų.

Negauta statistiškai reikšmingos priklausomybès tarp streso dažnio ir respondentų šeiminès padèties $\left(\chi^{2}=22,6,11=16, p>0,05\right)$, streso dažnio ir to, kokioje šeimoje respondentas yra užaugęs (pilnoje, nepilnoje ir pan.; $\chi^{2}=15,0,11=16, p>0,05$ ), bei streso dažnio ir vietovès (didmiestis, miestelis ar kaimas), kurioje studentas gyvena $\left(\chi^{2}=15,0,11=8, p>0,05\right)$. Be to, streso dažnis nėra susijęs su tuo, ar studentas tik studijuoja, ar studijuodamas dar ir dirba apmokamą darbą $\left(\chi^{2}=7,4,11=4, \mathrm{p}>0,05\right)$.

Tačiau streso dažnis statistiškai reikšmingai priklauso nuo to, kuriame kurse mokosi studentas $\left(\chi^{2}=20,9,11=10, p<0,05\right)$. Dažnai arba labai dažnai stresą daugiausia jaučia pirmakursiai (20,2 proc.) ir antrakursiai (23,3 proc.) bakalaurai. Niekada nejaučiančių streso daugiausiai pasitaikè tarp ketvirtakursių bakalaurų (30,8 proc.).

Streso dažnis neturi koreliacinio ryšio su studento mokymosi pasiekimų vidurkiu, tačiau turi silpną, bet statistiškai reikšmingą ryši su tuo, kaip studentas yra patenkintas savo studijų pasiekimais - kuo labiau patenkinti savo pasiekimais, tuo rečiau jaučia stresą, ir atvirkščiai (Spearmano koreliacijos koeficientas lygus 0,2, p < 0,01).

Tiek moterys, tiek vyrai nurodo, kad dažniausiai stresą patiria universitete (lyginant su namais, jei dirba - darbu ir kitomis vietomis, kuriose studentas būna) - daugiau negu pusė respondentų (53,1 proc.).

Apibendrinti studentų streso dažnị lemiančių veiksnių rezultatai pateikti 1 lentelèje.

1 lentelè. Galimi streso dažnị lemiantys veiksniai

\begin{tabular}{|l|c|}
\hline \multicolumn{1}{|c|}{ Veiksniai, galintys veikti streso dažnį } & $\begin{array}{c}\text { Gautas statistiškai } \\
\text { reikšmingas poveikis }\end{array}$ \\
\hline Lytis & Taip \\
\hline Šeiminè padètis & $\mathrm{Ne}$ \\
\hline Kokioje šeimoje respondentas yra užaugęs & $\mathrm{Ne}$ \\
\hline Studento gyvenamoji vietovè & $\mathrm{Ne}$ \\
\hline
\end{tabular}




\begin{tabular}{|l|c|}
\hline Studentas dirba apmokamą darbą & $\mathrm{Ne}$ \\
\hline Kursas & Taip \\
\hline Pasiekimų vidurkis & $\mathrm{Ne}$ \\
\hline Pasitenkinimas savo studijų pasiekimais & Taip \\
\hline
\end{tabular}

Analizuojant atsakymų ị klausimą, kas respondentams sukelia stresą, duomenis faktorinès analizès būdu paaiškèjo, kad visus respondentų atsakymus galima suskirstyti $\mathfrak{i}$ tokius tris faktorius (klausimo vidinis patikimumas patikrintas pagal Kronbacho alfa rodiklį, lygų 0,8$)$ :

- socialiniai santykiai: sunkumai bendraujant su savo vaikinu / mergina, nesutarimai su draugais, patirta emociné, fizinè ar seksualinè prievarta, patyčios, sunkios ligos ir nelaimingi atsitikimai šeimoje ar ištikę artimiausius draugus;

- kasdiene įtampa: miego trūkumas, nuovargis, kasdienè rutina, nuolatinè itampa, priverstinis skubejimas;

- $\quad$ studijos: didelis mokymosi krūvis, egzaminai, atsiskaitymai, konkurencija tarp studentų, nesutarimai su dèstytojais.

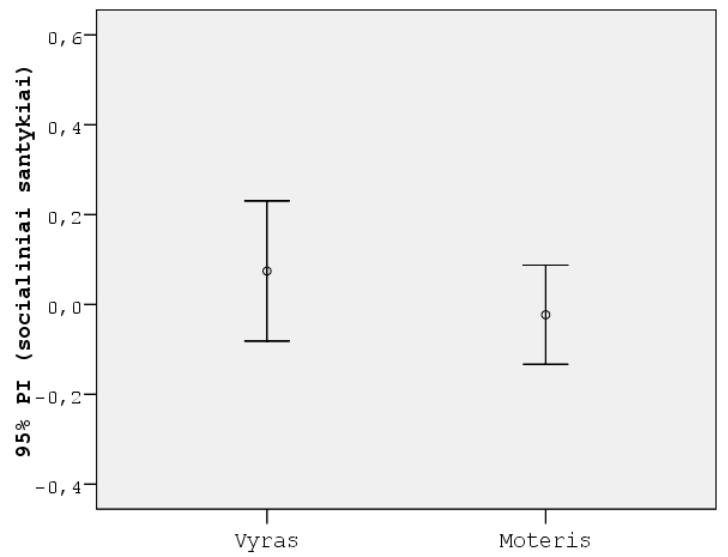

1 pav. Socialinių santykių faktoriaus poveikis vyrų ir moterų stresui

Kiekvienas iš trijų faktorių sudarytas imant Varimax sukinio matricos komponentų aukščiausias reikšmes. Jei grupuotume faktorius ne iš statistinių duomenų, o teoriškai, tai galètume sudaryti ir šiek tiek skirtingas faktorių grupes, pavyzdžiui, „nesutarimą su dėstytojais" būtų galima priskirti tiek socialinių santykių (nes kalbama apie asmenų tarpusavio santykius), tiek studijų (nes kalbama apie studijų reikalus) faktoriui. Be to, grupuojant teoriškai būtų galima kaip skirtingus faktorius išskirti 
skirtingo „emocinio svorio“ komponentus, tokius kaip „nesutarimas su draugais“ ir „patirta seksualiné prievarta“, kurie dabar patenka ị vieną faktorių. Taigi iš faktorių, gautų faktorinès analizès būdu, matyti, kad juos sudaro tiek skirtingo „emocinio svorio" komponentai, tiek pats komponentų skirstymas ị faktorius teoriškai nèra labai griežtas.

Analizuojant išskirtąsias tris streso sukèlejų grupes (faktorius) pagal lytị matyti, kad tiek moterims, tiek vyrams maždaug vienodai dažnai stresą sukelia socialiniai santykiai (žr. 1 pav., čia mažesnis skaičius reiškia dažniau jaučiamą stresą).

Tačiau kasdienès ịtampos sukeltą stresą žymiai dažniau patirti būdinga moterims (žr. 2 pav.). Studijų sukeltą stresą patirti taip pat yra linkę dažniau moterys nei vyrai.

Analizuojant ir bandant prasmingai sugrupuoti ịvairias studentų pasirenkamas streso ịveikos strategijas faktorinès analizès būdu paaiškèjo, kad visas strategijas galima suskirstyti $\mathfrak{i}$ tris faktorius (klausimo vidinis patikimumas patikrintas pagal Kronbacho alfa rodiklį, lygus 0,7, kiekvienas iš faktorių sudarytas imant Varimax sukinio matricos komponentų aukščiausias reikšmes):

- pozityvi savipagalba: klausosi muzikos, tiesiog eina miegoti, užsiima kokia nors malonia veikla, užsiima fizine veikla, šoka, eina pasivaikščioti, bendrauja su gyvūnais, stengiasi pažvelgti i probleminę situaciją kitaip, ieško paramos, stengiasi išspręsti problemą, bando iškilusią situaciją vertinti teigiamai;

- $\quad$ ieškojimas kitu pagalbos arba kitur (žmonių, Dievo, medicinos): kreipiasi i psichologą arba psichoterapeutą, meldžiasi, medituoja, geria raminamuosius vaistus, geria raminančią arbatą;

- negatyvi savipagalba: rūko, vartoja alkoholị arba narkotines medžiagas, persivalgo.

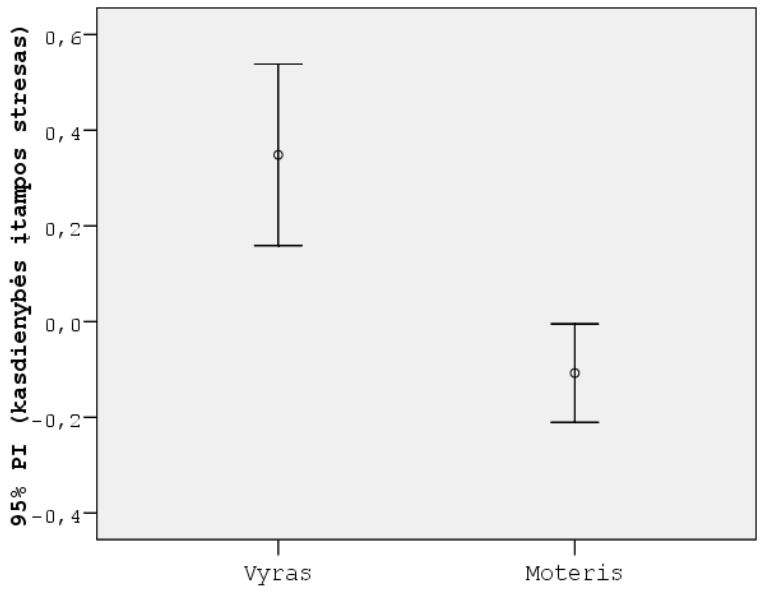

2 pav. Kasdienès įtampos faktoriaus poveikis vyrų ir moterų stresui 
Respondentai, kurie stresą keliančias situacijas supranta kaip kontroliuojamas, keičiamas ir galimas išspręsti, streso atveju dažniau renkasi pozityvios savipagalbos strategiją (Spearmano koreliacijos koeficientas lygus $0,4, \mathrm{p}<0,01$ ), o tie, kurie stresą keliančias situacijas suvokia kaip nekontroliuojamas ir laukia nesèkmès, dažniau pagalbos kreipiasi ị kitus arba kitur (Spearmano koreliacijos koeficientas lygus 0,3, $\mathrm{p}<0,01)$. Koreliacinio ryšio tarp požiūrio ị stresą keliančias situacijas ir negatyvios savipagalbos pasirinkimo nenustatyta.

Palyginus streso ịveikos strategijas, paaiškejo, kad kitų pagalbos arba kitur (profesionalų, Dievo, medicinos) labiau linkusios ieškoti moterys (žr. 3 pav., čia mažesnis skaičius reiškia dažniau pasirenkamą streso įveikimo strategiją). Kaip matyti, vyrai stresui ịveikti kitų pagalbos beveik nesirenka.

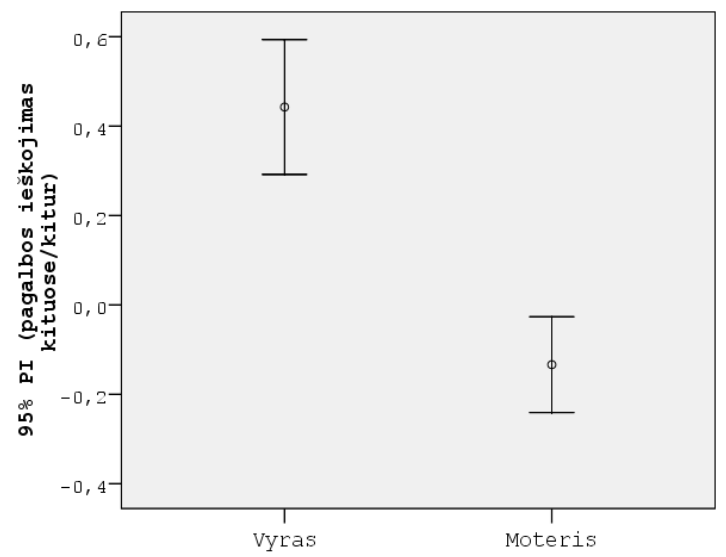

3 pav. Vyrų ir moterų streso ịveikos strategijos - kitur arba kitų pagalbos ieškojimas (žmonių, Dievo, medicinos) - pasirinkimas

Kalbant apie streso įveikos strategiją kaip negatyvios savipagalbos ieškojimą gauti atvirkštiniai rezultatai - šiuo atveju ši strategija priimtinesnè vyrams negu moterims (žr. 4 pav.).

Pozityvios savipagalbos strategija maždaug vienodai patraukli tiek vyrams, tiek moterims - reikšmingo skirtumo tarp lyčių nenustatyta. 


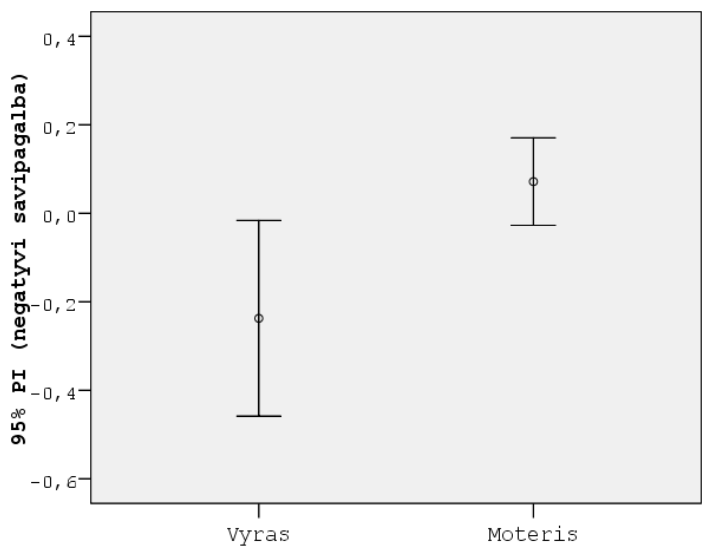

4 pav. Vyrų ir moterų streso ịveikos strategijos - negatyvios savipagalbos - pasirinkimas

Iš 5 paveikslo matyti (čia mažesnis skaičius reiškia dažniau pasirenkamą streso ìveikos strategiją), kad streso įveikos pasirinkimo strategijos yra susijusios su tuo, kaip dažnai respondentas stresą patiria. Jei respondentas stresą patiria dažnai arba labai dažnai, jam būdinga kreiptis pagalbos ị kitus, jei respondentas stresą patiria retai, kartais, jis linkęs su juo susidoroti pats ir pozityviai (pozityvi savipagalba), ir jei respondentas streso paprastai nepatiria, susidūręs su stresine situacija jis labiau linkęs ị negatyvią savipagalbą (paveiksle būdinga streso ịveikos pasirinkimo strategija išryškinta kitu šriftu).
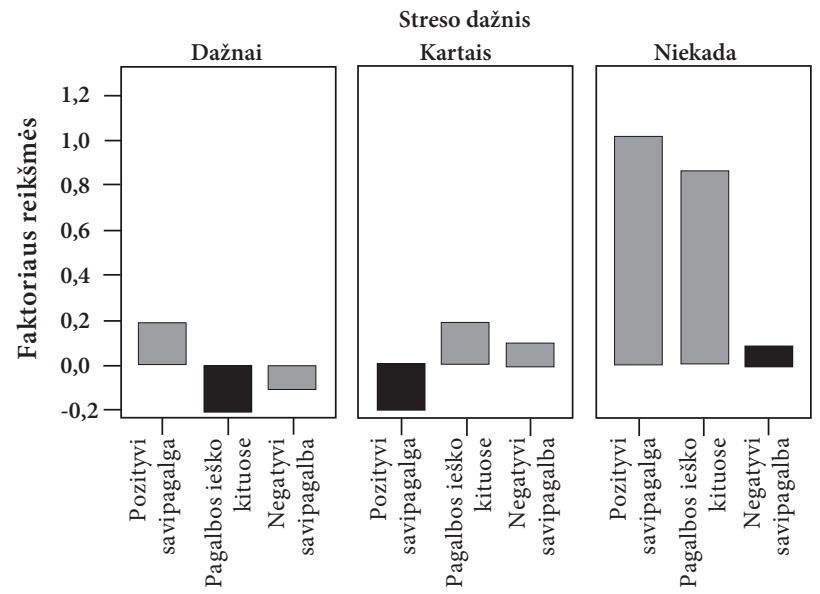

5 pav. Streso įveikos strategijų sąsaja su patiriamo streso dažnumu 


\section{Rezultatų aptarimas}

Tyrimo rezultatai atskleide, kad MRU studentams stresas yra dažna problema ir beveik pusè studentų, patiriančių stresą, jị jaučia dažnai. D. Karkockienės ${ }^{21}$, tyrusios Vilniaus universiteto Medicinos fakulteto ir Panevėžio kolegijos Medicinos ir socialinių mokslų fakulteto studentų stresą, tyrimo rezultatai taip pat atskleidė, kad 50 proc. universiteto ir 38,5 proc. kolegijos studentų stresą patiria dažnai. R. W. May ir S. P. Casazza ${ }^{22}$ tyrimai rodo, kad daugiau streso patiria pirmo kurso studentai negu aukštesniųjų kursų studentai. Šio straipsnio autorių tyrimo duomenys taip pat rodo, kad stresą dažniausiai jaučia pirmakursiai ir antrakursiai bakalaurai. Tačiau yra duomenų, kad stresą dažniau patiria ne tik pirmo, bet ir baigiamojo kurso studentai ${ }^{23}$.

Mūsų tyrimo metu nustatytas statistiškai reikšmingas ryšys tarp streso jautimo dažnio ir lyties: moterys linkusios stresą jausti dažniau nei vyrai. Tai patvirtina ir kitu autorių tyrimai ${ }^{24}$. Atlikto tyrimo duomenys rodo, kad respondentams stresą sukelia santykiai su žmonèmis, kasdienè įtampa, atsirandanti dèl miego trūkumo, priverstinio skubejjimo, nuolatinès ịtampos ir studijos, kai laikomi egzaminai, vyksta atsiskaitymai, jaučiama konkurencija tarp studentų, patiriami nesutarimai su dėstytojais, mokymosi krūviai yra dideli. Kad studijos yra vienas dažniausių stresorių studentams patvirtina ir A. Bagdono ${ }^{25}$, L. Sapranavičiūtès ir kt. ${ }^{26}$, D. Karkockienès ${ }^{27}$ tyrimai.

Stresogeninių reiškinių ịveikai skiriama nemažai dèmesio, bet vis dèlto neprieinama prie bendros išvados klasifikuojant stresogeninių situacijų įveikos strategijas. Kuriant teorinius streso ir jo įveikos modelius ir atliekant empirinius tyrimus, išryškejja skirtingos streso ịveikos strategijos ${ }^{28}$. Tai lemia teoriškai pagrịstų ir psichometriškai adekvačių metodikų îveikai tirti stoka. Viena didžiausių problemų yra tai,

21 Karkockienè, D., supra note 2, p. 83-92.

22 May, R. W.; Casazza, S. P. Academic major as a perceived stress indicator: extending stress management intervention. College Student Journal. 2012, 46(2): 264-273.

23 Shaikh, S.; Shaikh, A. H.; Magsi I. Stress among medical Students of University of Interior Sindh. Medical Channel. 2010, 16(4): 538-540.

24 Brougham, R. R.; Zail, C. M.; Mendoza, C. M.; Miller, J. R. Stress, Sex Differences, and Coping Strategies Among College Students. Current Psychology. 2009, 28: 85-97; Poltavski, D.; Ferraro, F. R. Stress and illness in American and Russian college students. Personality and Individual Differences. 2003, 34: 971-982; Tavolacci, M. P.; Ladner, J.; Grigioni, S.; Richard L; Villet, H.; Dechelotte, P. Prevalence and association of perceived stress, substance use and behavioral addictions: a cross-sectional study among university students in France, 2009-2011. BMC Public Health. 2013, 13(1): 1-8.

25 Bagdonas, A. Egzaminų baimè: raiškos ypatumai ir sprendimo galimybès. Mokslo taikomieji tyrimai Lietuvos kolegijose. 2009, 6: 20-30.

26 Sapranavičiūte, L.; Perminas, A., supra note 11, p. 98-107.

27 Karkockiene, D., supra note 2, p. 83-92.

28 Valickas, G.; Grakauskas, Ž.; Želvienè, P. Patobulinto keturių faktorių streso įveikos klausimyno psichometriniai rodikliai. Psichologija. 2010, 41: 96-110. 
kad streso ịveikimo strategijos tiriamos skirtingomis metodikomis ir todèl sunkiau palyginti tyrimų rezultatus ${ }^{29}$.

Atlikto tyrimo stresogeninių situacijų îveikos faktorinė analizė atskleidè, kad MRU studentams būdinga trijų faktorių streso ịveikos strategijų struktūra: pastangos pozityviai padèti sau, pagalbos ieškojimas kreipiantis ị kitus arba kitur ir negatyvi savipagalba.

L. Sapranavičiūtès ir kt. ${ }^{30}$ stresogeninių situacijų ịveikos faktorinė analizè atskleidè, kad universiteto studentams būdinga aštuonių faktorių stresogeninių situacijų ịveikos strategijų struktūra: ị problemą nukreipta ịveikos strategija, emocijų išliejimo, socialinès paramos paieškos, dèmesio nukreipimo, neigimo, atsigręžimo ị religiją, svaigalų vartojimo ir susitaikymo ịveikos strategijos. R. S. Lazarus ${ }^{31}$ skiria du streso ịveikimo būdus: ị problemą ir ị emocijas orientuotus įveikimo būdus. N. S. Endler, J. D. A. Parker ${ }^{32}$ sukūrè stresogeninių situacijų ịveikos modelį, kurị sudaro trys ịveikos. Jie prie anksčiau minètų i emocijas ir ị problemą nukreiptų ịveikos būdų dar prijungè ị vengimą nukreiptą ịveiką. Toks dar vienos ịveikos išskyrimas yra reikalingas, nes i problemą nukreiptos ịveikos koncentruojasi $\mathfrak{i}$ situaciją, $\mathfrak{i}$ emocijas nukreiptos îveikos pabrèžia dèmesị asmeniui, o su vengimu susijusios ịveikos strategijos gali būti

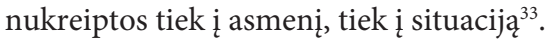

Atlikto tyrimo duomenys rodo, kad moterys ir vyrai taiko skirtingas streso įveikimo strategijas. Moterys dažniau už vyrus ieško kitų žmonių, medikų pagalbos, tuo tarpu vyrai stresą bando ịveikti rūkydami, vartodami alkoholị ar kitas narkotines medžiagas. L. Sapranavičiūtè ir kt. ${ }^{34}$ taip pat teigia, kad moterys dažniau naudoja socialinès paramos paieškos, emocinès iškrovos įveikas, o vyrai dažniau už moteris kaip ịveikimo strategiją pasirenka alkoholị ar narkotikus. Taip pat moterys aktyviau pasitelkia ị emocijas nukreiptą ịveikos strategiją ir vengimą. C. C. Riddock ${ }^{35}$ duome- $^{-}$ nimis, moterys taiko žymiai daugiau streso ịveikos strategijų negu vyrai (pokalbiai su draugais, specialistų konsultacijos, maistas, TV, apsipirkinejjimas, aromaterapija ir kt.), tačiau Y. Li ir J. L. Billie ${ }^{36}$ teigia priešingai: studentai vyrai yra linkę daugiau laiko skirti kasdienei relaksacijai, naudoti specifinius streso kontrolès metodus, o mažiau stresuojantys dažniau dalyvauja sveikatinimo programose. Pripažįstama, kad žmogus turi savo ịprastinius streso ịveikimo būdus, dažniausiai taikomus tam tikrose

29 Sapranavičiūtè, L.; Perminas, A.; Kavaliauskaitė, E., supra note 7, p. 9-28.

30 Ibid.

31 Lazarus, R. S. Emotions and interpersonal relationships: Toward a person - centered conceptualization of emotions and coping. Journal of Personality. 2006, 74: 9-46.

32 Endler, N. S.; Parker, J. D. A. Multidimensional assessment of coping: a critical evaluation. Journal of personality and Social Psychology. 1990, 58(5): 844-854.

33 Sapranavičiūtè, L.; Perminas, A.; Kavaliauskaite, E., supra note 7, p. 9-28.

34 Ibid.

35 Riddock, C. C., supra note 9, 24-44.

36 Li, Y.; Billie, J. L. An association between college students' health promotion practices and perceived stress. College Student Journal. 2013, 47(3): 437-446. 
stresinėse situacijose. Asmenys dažniausiai neieško vis kito streso ịveikimo būdo, o pasitelkia anksčiau taikytus, išbandytus ir žinomus ${ }^{37}$.

Apibendrinus skirtingų autorių duomenis apie streso paplitimą, priežastis, ịveikos strategijas, galima teigti, kad stresas yra aktuali studentų problema ịvairiose šalyse. Apie tai turètų žinoti visa akademinè bendruomenè. Taikant sẻkmingas streso ivveikos strategijas, gerejja pasitenkinimas gyvenimu ir subjektyvi gerovè. Žinant tai ir siekiant mažinti neigiamą streso įtaką sveikatai, jaunimą reiktų tikslingai mokyti susiformuoti streso ịveikos ịgūdžius. Tai būtina daryti nuo mokymosi aukštojoje mokykloje pradžios, o dar geriau - nuo vidurinès mokyklos. Pirmakursius reiktų skatinti naudoti ịvairias efektyvias ịveikos strategijas ir atsirinkti, kurios efektyviausios konkrečiam individui. Konsultuojant studentus dèl streso, kuriant intervencines sveikatinimo programas, būtina atsižvelgti ị lytinius streso lygio ir streso įveikos strategiju pasirinkimo skirtumus, įdiegti sveikatos ugdymo programas, kuriose mokoma keisti elgesị i sveikatai palankų, organizuoti seminarus, kuriuose studentai galètu praktiškai išbandyti efektyvias streso ịveikos technikas. Streso įveikos programos ir konsultacijos turètų būti prieinamos visiems studentams. Prieinamumą galètų padidinti individualiai pritaikomos savipagalbos programos internete.

\section{Išvados}

Tyrimo duomenys atskleide, kad dauguma MRU studentų (90,0 proc.) patiria stresą. Streso dažnis susijęs su respondentų lytimi (moterys jaučia stresą dažniau nei vyrai), studijų metais (pirmakursiai ir antrakursiai patiria stresą dažniau nei ketvirtakursiai) ir studijų pasiekimais (rečiau jaučia stresą studentai, patenkinti savo pasiekimais nei nepatenkinti). Tyrimo rezultatai parodè, kad MRU studentams stresą sukelia socialiniai santykiai, kasdienę įtampa ir studijos universitete.

MRU studentams būdingos trys streso įveikos strategijos: pozityvi savipagalba, pagalbos ieškojimas kreipiantis ị kitus arba kitur (ị žmones, Dievą, mediciną); negatyvi savipagalba.

Sèkminga streso įveika turètų būti visos akademinès bendruomenès rūpestis. Būtina užtikrinti, kad kiekvienas studentas turètų galimybę igyti efektyvių streso įveikos igūdžiuę, o prireikus gauti individualias specialistų konsultacijas.

\section{Literatūra}

Bagdonas, A. Egzaminų baimè: raiškos ypatumai ir sprendimo galimybès. Mokslo taikomieji tyrimai Lietuvos kolegijose. 2009, 6.
Brougham, R. R.; Zail, C. M.; Mendoza, C. M.; Miller, J. R. Stress, Sex Differences, and Coping Strategies Among College Students. Current Psychology. 2009, 28. 
Bulotaitè, L., et al. Universitetų dèstytojų darbo ir streso ypatumai. Acta paedagogica Vilnensia. 2008, 21.

Chylova, H.; Natovova, L. H. Stress coping strategies at university students part I: gender differences. Journal on Efficiency and Responsibility in Education and Science. 2012, 5(3).

De Kloet, E. R.; Joëls, M.; Holsboer, F. Stress and the brain: from adaptation to disease. Nature reviews: Neuroscience. 2005, 6(6).

Endler, N. S.; Parker, J. D. A. Multidimensional assessment of coping: a critical evaluation. Journal of personality and Social Psychology. 1990, 58(5).

Houghton, J. D.; Wu, J.; Godwin, J. L.; Neck, C. P.; Manz, C. C. Effective stress management: a model of emotional intelligence, self-leadership, and student stress coping. Journal of Management Education. 2012, 36(2).

Ivaškienė, V.; Kšanauskienė, L.; Čepelioniene், J.; Bogužienè, J.; Daukšas, D. Sportuojančių studentų (vyrų ir moterų) taikomi streso įveikimo būdai. Socialiniai mokslai. 2009, 3(74).

Jusienè, R.; Platkevičiūtè, V. Motinų streso įveikimo būdai ir vaikų emocijų bei elgesio sunkumai. Psichologija. 2003, 27.

Karkockienè, D. Medicinos ir sveikatos mokslų studentų patiriamo streso ypatumai ir jo ittaka miego kokybei. Visuomenés sveikata. 2011, 2(53).

Kausar, R. Perceived stress, academic workloads and use of coping strategies by university students. Journal of Behavioural Sciences. 2010, 20.

Lazarus, R. S. Emotions and interpersonal relationships: Toward a person - centered conceptualization of emotions and coping. Journal of Personality. 2006, 74.

Li, Y.; Billie, J. L. An association between college students' health promotion practices and perceived stress. College Student Journal. 2013, 47(3).
May, R. W.; Casazza S. P. Academic major as a perceived stress indicator: extending stress management intervention. College Student Journal. 2012, 46(2).

Mostafaei, A. The relationship between stress and mental health in university students. Scholars Research Library. Annals of Biological Research. 2012, 3(7).

Norkus A.; Alūzas R. Studentų sveikatos ugdymas aukštosiose mokyklose: galimybès ir problemos. Studijos šiuolaikinejje visuomenejje. 2012, 3(1).

Odaci, H.; Çıkrıkçı, Ö. University students' ways of coping with stress, life satisfaction and subjective well-being. Online journal of Counseling and education. 2012, 1(3).

Perminas, A.; Galvydienè, A. Studentų sveikos mitybos bei streso ivveikimo strategijų sąsajos. Tarptautinis psichologinis žurnalas: biopsichosocialinis požiūris. 2008, 1.

Poltavski, D.; Ferraro, F. R. Stress and illness in American and Russian college students. Personality and Individual Differences. 2003, 34.

Por, J.; Barriball, L.; Fitzpatric, L.; Roberts, J. Emotional intelligence: Its relationship to stress, coping, wellbeing and professional performance in nursing students. Nurse Education Today. 2011, 31.

Riddock, C. C. What to Do About Being Overwhelmed: Graduate Students, Stress and University Services. College Student Affairs Journal. 2007, 279(1).

Sapranavičiūtè, L.; Perminas, A. Universiteto studentų naudojamų streso įveikimo strategijų ir nusiskundimų sveikata sąsajos. Visuomenès sveikata. 2011, 1(52).

Sapranavičiūtè, L.; Perminas, A.; Kavaliauskaitè, E. Universiteto studentu stresogeninių situacijų íveikos strategijų struktūra. Tarptautinis psichologijos 
žurnalas: biopsichosocialinis požiūris. 2011, 8.

Shaikh, S.; Shaikh, A. H.; Magsi, I. Stress among medical Students of University of Interior Sindh. Medical Channel. 2010, 16(4).

Tavolacci, M. P.; Ladner, J.; Grigioni, S.; Richard, L; Villet, H.; Dechelotte, P. Prevalence and association of perceived stress, substance use and behavioral addictions: a cross-sectional study among university students in France, 2009-2011. BMC Public Health. 2013,13(1).
Valickas, G.; Grakauskas, Ž.; Želvienè, P. Patobulinto keturių faktorių streso iveikos klausimyno psichometriniai rodikliai. Psichologija. 2010, 41.

Welle, P. D.; Graf, H. M. Effective lifestyle habits and coping strategies for stress tolerance among college students. American Journal of Health Education. 2011, 42(2).

Zaborskis, A.; Vareikienè, I. Patyčios mokykloje ir jų sąsajos su moksleivių sveikata bei gyvensena. Medicina. 2008, 44(3).

\title{
STRESS EXPERIENCED BY STUDENTS OF MYKOLAS ROMERIS UNIVERSITY AND STRATEGIES FOR COPING WITH IT
}

\author{
Jolita Dudaitè \\ Mykolas Romeris University, Lithuania \\ Stasè Ustilaitè \\ Lithuanian University of Educational Sciences, , Lithuania
}

\section{Summary.}

Aim of the article - to evaluate stress experienced by Mykolas Romeris University students and to identify stress coping strategies.

Methods. The study was carried out in September-December of 2012 at Mykolas Romeris University. The questionnaire was used as the survey method. The sample consisted of randomly selected 450 students. The students of all courses - both undergraduates and postgraduates - participated in the survey. The age of students was from 19 to 25 years old. The following data analysis methods were used: Cronbach's alpha index, Pearson's $\chi^{2}$ test, Spearman's correlation, factor analysis with Varimax rotation.

Results and conclusions. The data show that 90 percent of respondents feel stress. Women tend to feel more stress than men. More than a half of the women (51.8 percent) indicated that they feel stress often or very often, while the same answer was given by less than a quarter of men (23.6 percent). Factor analysis revealed that all stress factors can be grouped into three main factors: social relationships (difficulties in communicating with boyfriend/girlfriend, disagreements with friends, emotional, physical or sexual abuse, bullying, serious illness and accidents of family members or of close friends); everyday stress (lack of sleep, fatigue, rush); study problems (high load training, exams, 
competition between students, odds with professors). It was found that Mykolas Romeris University students have three main stress coping strategies: positive self-help (listening to music, going to sleep, engaging in any physical activity or other enjoyable activities, dancing, going for a walk, interacting with animals, trying to look at the problematic situation differently, looking for support, trying to resolve the problem, trying to look to the situation in a positive way); looking for support in others or elsewhere: in humans, God or medicine (going to a psychologist or psychotherapist, praying, meditating, using sedatives, drinking soothing tea), negative self-help (smoking, alcohol, drugs, overeating).

Keywords: student stress, stress coping strategies.

Jolita Dudaitė, Mykolo Romerio universiteto Socialinių technologijų fakulteto Edukologijos ir socialinio darbo instituto lektorè. Mokslinių tyrimų kryptys: socialinių tyrimų metodologija, testų teorija, lyginamieji švietimo tyrimai, verslumas, švietimo kokybė, gyvenimo kokybè.

Jolita Dudaitė, Mykolas Romeris University, Faculty of Social Technologies, Institute of Educational Sciences and Social Work, lecturer. Research fields: methodology of Social Sciences, test theory, comparative educational research, entrepreneurship, quality of education, quality of life.

Stasė Ustilaitė, Lietuvos edukologijos universiteto Sporto ir sveikatos fakulteto Sveikatos ir fizinio ugdymo katedros docentè. Mokslinių tyrimų kryptys: lytiškumo ugdymas, sveikatos ugdymas.

Stasė Ustilaitė, Lithuanian University of Educational Sciences, Faculty of Sports and Health Education, Department of Health and Physical Education, Associate Professor. Research fields: sexuality education and health education. 